\title{
INDEX TO VOLUME 146
}

$\begin{array}{lr}\text { PART I-SUBJECTS } & 1-10 \\ \text { PART II-CONTRIBUTORS } & 10-14 \\ \text { PART II-BOOK REVIEWS } & 15-17 \\ \text { ACKNOWLEDGEMENT TO ASSESSORS } & 18\end{array}$




\section{Index to Volume 146}

\section{PART I SUBJECTS \\ Compiled by A. Stanley Thorley}

Abbreviations: AIDS-Acquired Immune Deficiency Syndrome; C-Correspondence; CT-Computerised Tomography; DST - Dexamethasone Suppression Test; ECT-Electroconvulsive therapy; MAO-Monoamine Oxidase; PSE-Present State Examination

Accident neurosis: Follow-up study of accident neurosis: Michael J. Tarsh and Claire Royston 18-25

Accident neurosis and the law; John Mitchell (C) 669

Acquired Immune Deficiency Syndrome (AIDS): 'PseudoAIDS' syndrome following from fear of AIDS; David Miller et al (Brief Report) 550-551

Adolescence: Gilles de la Tourette syndrome and mania in an adolescent; A. Bleich et al (Brief Report) 664-665

Outcome of anorexia nervosa in younger subjects; Richard M. Hawley $657-660$

Pairs of same-sexed siblings discordant for anti-social behaviour; Marge Reitsma-Street et al 415-423

Repetition of self-poisoning and subsequent death in adolescents who take overdoses; Michael Goldacre and Keith Hawton 395-398

Suicide and parasuicide in childhood and early adolescence; Donald J. Brooksbank (Annotation) 459-463

Affective disorders: Changes in the diagnoses of the functional psychoses associated with the introduction of lithium; Gordon Parker et al 377-382

Familial transmission of major affective disorders. Is there evidence supporting the distinction between unipolar and bipolar disorders? Ming T. Tsuang $e t$ al 268-271

Hereditary differentiation of anxiety and affective neuroses; Svenn Torgersen 530-534

Impact of lithium in South-west Scotland I. Demographic and clinical findings; R. G. McCreadie and D. P. Morrison 70-74 II. Longitudinal study; D. P. Morrison and R. G. McCreadie 74-77 III. Discontinuation of lithium; R. G. McCreadie et al 77-80.

Motor and sighting dominance in schizophrenia and affective disorder; Edward L. Merrin 539-544

Transient sensory, cognitive and affective phenomena in affective illness: Comparison with complex partial epilepsy; Edward K. Silberman et al 81-89

Treatment of rapid cycling affective illness; $M$. R. Lowe (C) 558

Affective symptoms: Anorexia and bulimia in anorexia nervosa; A. J. Yellowlees 648-652

Comparison of elective mutism and emotional disorders in children; Robert Wilkins 198-203

Emotional consequences of ejection, rescue and rehabilitation in Royal Air Force Aircrew; D. G. Fowlie and M. O. Aveline 609-613

Mood changes after childbirth; Kenneth C. M. Wilson (C) 215-216
Affect-laden words: Depression and affect-laden words; W. A. Lishman and G. C. Dunbar (C) 99

Africa, Western: Maggot in the salt, the snake factor and the treatment of atypical psychosis in West African women; Anne E. Farmer and Wojciech F. Falkowski (Brief Report) 446-448

Aggression: Pipothiazine palmitate in the management of aggressive mentally handicapped patients; $D$. M. Lynch et al 525-529

Agoraphobia: Familial occurrence of agoraphobia; Carmen Moran and Gavin Andrews 262-267

Marital adjustment and treatment outcome in agoraphobia; W. Monteiro et al 383-390

Psychological profile of the spouse of the female agoraphobic patient: personality and symptoms; Willem A. Arrindell and Paul M. G. Emmelkamp 405-415

Aircrew: Emotional consequences of ejection, rescue and rehabilitation in Royal Air Force aircrew; D. G. Fowlie and M. O. Aveline 609-613

Alcoholism: Alcoholics: a twenty year follow-up study; Art O'Connor and Joan Daly 645-647

Alprazolam: Evaluation of alprazolam in the treatment of reactive or neurotic (secondary) depression; Norman W: Imlah 515-519

Alzheimer's disease: Nuclear magnetic resonance (NMR): II. Imaging in dementia; J. A. O. Besson et al 31-35.

Amitriptyline: Evaluation of alprazolam in the treatment of reactive or neurotic (secondary) depression; Norman W. Imlah 515-519

Annotations: Alternatives to psychiatric hospitalisation; Digby Tantam 1-4

Fusarial mycotoxins and behaviour: possible implications for psychiatric disorder; R. Schoental 115-119

Hive system: a model for a psychiatric service; Peter Tyrer 571-575

Suicide and parasuicide in childhood and early adolescence; Donald J. Brooksbank 459-463

Anorexia: Anorexia and bulimia in anorexia nervosa: study of psychosocial functioning and associated psychiatric symptomatology; A. J. Yellowlees 648-652

Anorexia nervosa in patients of Afro-Caribbean extraction; Joseph P. Thomas and George I. Szmukler 653656

Binges, vomiting and guilt; Jennifer Bearn and Paul Robinson (C) 214

Measurement of body image in anorexia nervosa; Melanie Taylor et al (C) 214-215

Outcome of anorexia nervosa in younger subjects; Richard M. Hawley $\quad 657-660$

Antidepressants: Does the dexamethasone suppression test predict antidepressant treatment success?; Alec Coppen et al 294-296

Anxiety disorders: Hereditary differentiation of anxiety and affective neuroses; Svenn Torgersen 530-534 
Professional and non-professional intervention for highly anxious primiparous mothers; Bryanne Barnett and Gordon Parker 287-293

Anthropology: Social anthropology in relation to psychiatry; Roland Littlewood (Reading about ... .) 552554

Atheroma: Atheroma, infarction and dementia: need for a new name; B. Mahendra et al (C) 211

Basaglia, Franco: Denial of the institution. A critical review of Franco Basaglia's writings; Raffaello Papeschi 247-254

Understanding the Italian experience; Kathleen Jones and Alison Poletti 341-347

Behaviour: Behaviour and skills of severely retarded adults in hospitals and small residential homes; Sally Rawlings $358-366$

Fusarial mycotoxins and behaviour: possible implications for psychiatric disorder; R. Schoental (Annotation) 115-119

Pairs of same-sexed siblings discordant for antisocial behaviour; Marge Reitsma-Street et al 415-423

Use of lithium in severely demented patients with behavioural disturbance; Anthony Holton and Kuruvilla George (C) 99-100

Behaviour therapy: Cognitive behavioural group treatment of bulimia; John A. Schneider and W. Stewart Agras 66-69

Marital adjustment and treatment outcome in agoraphobia; W. Monteiro et al 383-390

Bereavement: Bereavement; Colin Murray Parkes (Review Article) 11-17

Biological antagonism: Biological antagonism and epileptic psychosis; P. Wolf and M. R. Trimble 272-276

Binges: Binges, vomiting and guilt; Jennifer Bearn and Paul Robinson (C) 214

Body image: Measurement of body image in anorexia nervosa; Melanie Taylor et al (C) 214-215

Brain-fag syndrome: Brain-fag syndrome in Nigeria: Cognitive deficits in an illness associated with study; Olufemi Morakinyo (Brief Report) 209-210

Brief reports: Aftercare of the patient with the neuroleptic malignant syndrome; Dov Aizenberg et al 317-318

Attempted infanticide; A. J. Wilkins 206-208

Brain-fag syndrome in Nigeria: Cognitive deficits in an illness associated with study; Olufemi Morakinyo 209-210

British opiate addicts: An 11-year follow-up; David Cottrell et al $448-450$

De Clérambault's syndrome-a nosological entity?; Peter Ellis and Graham Mellsop 90-93

Erotomania in Schneider-positive schizophrenia; Mary Hayes and Brian O'Shea 661-663

Gilles de la Tourette syndrome and mania in an adolescent; A. Bleich et al 664-665

Homicide in a psychiatric institution; Jiři Modestin and Wolfgang Böker 321-322

Huntington's chorea without dementia; a problem case; T. H. Turner 548-550

Is mania compatible with Down's syndrome? Robert Sovner et al 319-320
Maggot in the salt, the snake factor and the treatment of atypical psychosis in West African women; Anne E. Farmer and Wojciech F. Falkowski 446-448

Medical and psychological investigation of psychogenic polydipsia: a case study; J. Kulkarni et al 545-547

Neuroleptics serum levels measured by radioreceptor assay in patients receiving intramuscular depot neuroleptics. Some preliminary findings; John Turbott $e t$ al $439-442$

Neurotic patients who terminate their own treatment; Howard Roberts 442-445

Pisa syndrome: report of two cases; Ramzy Yassa 93-95

'Pseudo-AIDS' syndrome following from fear of AIDS; David Miller et al 550-551

Relapsing folie à trois; F. P. Fernando and M. Frieze 315-316

Why teetotallers abstain; Jennifer Hughes et al 204-206

Broadmoor Asylum: A hundred years ago; Henry $\mathbf{R}$. Rollin 458

Bulimia: Anorexia and bulimia in anorexia nervosa; A. J. Yellowlees 648-652

Anorexia nervosa in patients of Afro-Caribbean extraction; Joseph P. Thomas and George I. Szmukler 653656

Binges, vomiting and guilt; Jennifer Bearn and Paul Robinson (C) 214

Cognitive behavioural group treatment of bulimia; John A. Schneider and W. Stewart Agras 66-69

Suppression of eating by fenfluramine in patients with bulimia nervosa; P. H. Robinson et al 169-176

Caudate nucleus: Tritiated etorphine and naloxone binding to opiate receptors in caudate nucleus in schizophrenia; F. Owen et al 507-509

Cerebral infarction: Atheroma, infarction and dementia: need for a new name; B. Mahendra et al (C) 211

Cerebral ventricles: Schizophrenia with good and poor outcome. II: Cerebral ventricular size and its clinical significance. A. O. Williams et al 239-246

Cerebrospinal fiuid: Cytomegalovirus and schizophrenia: a test of a viral hypothesis; Satish Shrikhande et al 503-506

Childbirth: Mood changes after childbirth; Kenneth $\mathrm{C}$. M. Wilson (C) 215-216

Children: Comparison of elective mutism and emotional disorders in children; Robert Wilkins 198-203

Examining children who are Wards of Court; Jason Maratos (C) 216

Postnatal depression and child development: a three-year follow-up study; R. M. Wrate et al $622-627$

Risk of child abuse among mothers who attempt suicide; Keith Hawton et al 486-489

Suicide and parasuicide in childhood and early adolescence; Donald J. Brooksbank (Annotation) 459-463

Chronicity: Chronicity and the General Health Questionnaire; M. E. Goodchild and Paul Duncan-Jones 5561

Prevalence of chronic psychiatric morbidity: a community sample; Brian Stanley and Andrew J. Gibson 372-376 
Circadian rhythms: Circadian rhythms; Chris Thompson (C) 557-558. Peter P. Roy-Byrne et al (C) 558

Classification: De Clérambault's syndrome-a nosological entity? Peter Ellis and Graham Mellsop (Brief Report) 90-93. Alistair Munro (C) 561

Depressive illness and morbid distress-Onset and development data examined against five-year outcome. J. R. M. Copeland 297-307

Multiaxial classification of male sexual dysfunction: Otto Benkert et al 628-632

Toward a biochemical classification of depressive disorders IX: DST results and platelet MAO activity; Alan F. Schatzberg et al $\quad 633-637$

Clinical judgements: Clinical judgements of selfdramatisation: a test of the sexist hypothesis; P. R. Slavney and G. A. Chase 614-617

Cognition: Schizophrenia with good and poor outcome. III. neurological 'soft' signs, cognitive impairment and their clinical significance; T. Kolakowska et al 348-357

Short-term cognitive effects of unilateral and bilateral ECT; Michael Alan Taylor and Richard Abrams 308311

Comments: Did Shakespeare know schizophrenia? The case of poor mad Tom in King Lear; Nigel $M$. Bark 436-438

Vampirism-a clinical condition; Herschel Prins 666668

What price psychotherapy? a rejoinder; Sidney Bloch and Michael J. Lambert 96-98

Community mental health services: Alternatives to psychiatric hospitalisation; Digby Tantam (Annotation) 14

Close encounters in general practice: experiences of a psychotherapy liaison team; Stephen Wilson and Katherine Wilson 277-281

Hive system: a model for a psychiatric service; Peter Tyrer (Annotation) 571-575

Needs of young intellectually retarded adults; F. S. W. Brimblecombe (18th Blake Marsh lecture, February 1984) 5-10

Compliance: see Patient compliance

Computerised tomography (CT): CT scans in schizophrenia; Michael A. Reveley 367-371

Contraception: Oral contraception and serious psychiatric illness: absence of an association; M. P. Vessey et al 4549

Corrections: Schizophrenic patients discharged from hospital-a follow-up study (Johnstone et al, Journal December 1984, 586-590); Eve C. Johnstone (C) 216

Water intoxication in psychiatric patients Satnam Singh $e t$ al 127-131; 562

Cortisol: Plasma cortisol levels in mania: associated clinical ratings and changes during treatment with haloperidol; J. C. Cookson et al 498-502

Cytomegalovirus: Cytomegalovirus and schizophrenia: a test of a viral hypothesis; Satish Shrikhande et al 503506

Day Care: Evaluation of day hospitals; Frank Holloway (C) 104
Deafness: Study of 250 patients referred to a department of psychiatry for the deaf; John C. Denmark 282-286

De Clérambault's syndrome: De Clérambaut's syndrome-a nosological entity? Peter Ellis and Graham Mellsop. (Brief report) $90-93$

Alistair Munro (C) 561

Erotomania in Schneider-positive schizophrenia: a case report; Mary Hayes and Brian O'Shea (Brief report) 661-663.

Delusions: Organic delusions: phenomenology, anatomical correlations and review; Jeffrey L. Cummings 184-197.

Subcultural delusions and hallucinations. Comments on the Present State Examination in a multi-cultural context; L. Swartz et al 391-394.

Dementia: Atheroma, infarction and dementia: need for a new name; B. Mahendra et al (C) 211.

Huntington's chorea without dementia; T. H. Turner (Brief report) 548-550.

Language in dementia; Robert E. Kuttner (C) 211-212. Reversible dementia and depression; Peter V. Rabins and Gerald Nestadt (C) 212-213.

Use of lithium in severely demented patients with behavioural disturbance; Anthony Holton and Kuruvilla George (C) 99-100.

Value of routine X-rays in dementia; E. B. Renvoize et al (C) 560 .

Dementia, multi-infarct: Nuclear magnetic resonance (NMR): II Imaging in dementia; J.A.O. Besson et al 31-35.

Depersonalisation: Relaxation and depersonalisation; Jack D. Edinger (C) 103.

Depot maintenance: Long-term depot maintenance of chronic schizophrenic out-patients: The seven year follow-up of the Medical Research Council fluphenazine/placebo trial; D. A. Curson et al 464 480.

Depression: Combined psychotherapy and pharmacotherapy for depression-the compliance variable; J. T. Condon (C) 670-671.

Depression and affect-laden words; W. A. Lishman and G. C. Dunbar (C) 99.

Depression and pharmacological treatment; Shalom Feinberg (C) 103-104.

Evaluation of alprazolam in the treatment of reactive or neurotic (secondary) depression; Norman W. Imlah 515-519.

Long-term depot maintenance of chronic schizophrenic out-patients. II. The incidence of compliance problems, side-effects, neurotic symptoms and depression; D. A. Curson et al 469-474.

Postnatal depression and child development: a three-year follow-up study; R. M. Wrate et al 622-627.

Predicting improvement in patients with non-endogenous depression; Gordon Parker et al 132-139.

Present status of Monoamine Oxidose inhibitors; C. M. B. Pare (Review article) 576-584.

Reversible dementia and depression; Peter V. Rabins and Gerald Nestadt (C) 212-213. 
Depressive disordcrs: Depressive illness and morbid distress. Onset and development examined against fiveyear outcome; J. R. M. Copeland 297-307.

Dexamethasone Suppression Test; C. A. Gagiano et al (C) 452 .

Does the dexamethasone suppression test predict antidepressant treatment success? Alec Coppen et al 294 296.

Nottingham ECT study: double-blind comparison of bilateral, unilateral and simulated ECT in depressive illness; S. Gregory et al 520-524.

Oral contraception and serious psychiatric illness: absence of an association; M. P. Vessey et al 45-49.

Short-term cognitive effects of unilateral and bilateral ECT; Michael Alan Taylor and Richard Abrams 308311.

Speech pause time as a method for the evaluation of psychomotor retardation in depressive illness; G. M. A. Hoffmann et al 535-538.

Toward a biochemical classification of depressive disorders IX: DST results and platelet MAO activity; Alan Schatzberg et al 633-637.

Dexamethasone Suppression Test (DST): Dexamethasone Suppression Test; C. A. Gagiano et al (C) 452.

Does the Dexamethasone Suppression Test predict antidepressant treatment success? Alec Coppen et al 294 296.

Toward a biochemical classification of depressive disorders IX: DST results and platelet MAO activity; Alan F. Schatzberg et al 633-637.

Diagnoses: Changes in the diagnoses of the funtional psychoses associated with the introduction of lithium; Gordon Parker et al 377-382.

Decline in the diagnosis of schizophrenia among first admissions to Scottish mental hospitals from 1969-78; John M. Eagles and Lawrence J. Whalley 151-154.

Diagnostic issues in the hyperventilation syndrome; Christopher Bass and William Gardner (C) 101-102.

Long-term depot maintenance of chronic schizophrenic out-patients. I. Course of illness, stability of diagnosis, and the role of a special maintenance clinic; D. A. Curson et al 464-469.

Discussion: What price psychotherapy? Michael Shepherd 555-556. H. J. Eysenck 556-557.

Dominance, cerebral: Motor and sighting dominance in schizophrenia and affective disorder: evidence for right-hand grip strength prominence in paranoid schizophrenics and bipolar illness; Edward L. Merrin 539 544.

Down's syndrome: Is mania compatible with Down's syndrome? Robert Sovner et al (Brief report) 319320.

Drugs see Antidepressants, Hypnotics, Neuroleptics and Pharmacotherapy.

Alprazolam, Amitriptyline, Cortisol, Dexamethasone, Etorphine, Fenfluramine, Fluphenazine, Haloperidol, Lithium, Monoamine oxidase, Naloxone, Pipothiazine, Sulpiride, Temazepam and Zopiclone.

Drug therapy: Depression and pharmacological treatment; Shalom Feinberg (C) 103-104.
Dysmorphophobia: Disorders with overvalued ideas; Christopher S. Thomas (C) 215.

Dysmorphophobia; Michael A. Jenike (C) 326.

Dysmorphophobia or monosymptomatic hypochondriasis?; Christopher S. Thomas (C) 672-673.

Dystonic syndrome, new: Pisa syndrome: report of two cases; Ramzy Yassa (Brief report) 93-95.

Eating disorders see also Anorexia and Bulimia.

Eating disorders in schizophrenia; G. C. Lyketsos et al 255-261.

Egypt: Academic difficulty among male Egyptian University students: I. Association with psychiatric morbidity 140-144. II. Associations with demographic and psychological factors; Ahmed Okasha et al 144-150.

Electroconvulsive Therapy (ECT): Does the Dexamethasone Suppression Test predict antidepressant treatment success? Alec Coppen et al 294-296.

Impact of lithium in South-west Scotland. II. Longitudinal study; D. P. Morrison and R. G. McCreadie 74-77.

Leicester ECT trial: results in schizophrenia; S. Brandon et al 177-183.

Nottingham ECT study: double-blind comparison of bilateral, unilateral and simulated ECT in depressive illness; S. Gregory et al 520-524.

Short-term cognitive effects of unilateral and bilateral ECT; Michael Alan Taylor and Richard Abrams 308311.

Spontaneous seizures after ECT; Walter F. Daniel (C) $100-101$.

Electrotherapy: Electrostimulation and opiate withdrawal; Margaret A. Patterson (C) 213.

Enzyme immuno-assay: Cytomegalovirus and schizophrenia: a test of a viral hypothesis; Satish Shrikhande et al 503-506.

Epilepsy: Biological antagonism and epileptic psychosis; P. Wolf and M. R. Trimble 272-276.

Epileptic psychosis: evaluation of PSE profiles; M. M. Perez et al 155-163.

Transient sensory, cognitive and affective phenomena in affective illness: comparison with complex partial epilepsy; Edward K. Silberman et al 81-89.

Erotomania: De Clérambault's syndrome-a nosological entity? Peter Ellis and Graham Mellsop (Brief report) 90-93. Alistair Munro (C) 561.

Etorphine: Tritiated etorphine and naloxone binding to opioid receptors in caudate nucleus in schizophrenia; $F$. Owen et al 507-509.

Erotomania in Schneider-positive schizophrenia: a case report; Mary Hayes and Brian O'Shea (Brief report) 661-663.

Evaluation studies: Evaluation of day hospitals; Frank Holloway (C) 104.

Evoked potentials, somatosensory: Stable abnormalities in the lateralisation of early cortical somatosensory evoked potentials in schizophrenic patients; J. E. Cooper et al 583-593.

Families: Controlled trial of social intervention in the families of schizophrenic patients: two year follow-up; Julian Leff et al 594-600. 
Family health: Familial occurrence of agoraphobia; Carmen Moran and Gavin Andrews 262-267.

Familial transmission of major affective disorders. Is there evidence supporting the distinction between unipolar and bipolar disorders? Ming T. Tsuang et al 268-271.

Medical and psychological investigation of psychogenic polydipsia: a case study; J. Kulkarni et al (Brief report) 545-547.

Fenfluramine: Suppression of eating by fenfluramine in patients with bulimia nervosa; P. H. Robinson et al 169-176.

Fluphenazine: Long-term depot maintenance of chronic schizophrenic out-patients: The seven year follow-up of the Medical Research Council fluphenazine/placebo trial; D. A. Curson et al 464-480.

Folie à trois: A relapsing folie à trois; F. P. Fernando and M. Frieze (Brief report) 315-316.

Follow-up studies see also Outcome:

Alcoholics: a twenty year follow-up study; Art O'Connor and Joan Daly 645-647.

British opiate addicts: An 11-year follow-up; David Cottrell et al (Brief report) 448-450.

Controlled trial of social intervention in the families of schizophrenic patients: two year follow-up; Julian Leff et al 594-600.

Follow-up study of accident neurosis; Michael J. Tarsh and Claire Royston 18-25.

Long-term depot maintenance of chronic schizophrenic out-patients: The seven year follow-up of the Medical Research Council fluphenazine/placebo trial; D. A. Curson et al 464-480.

Post-natal depression and child development: a threeyear follow-up study; R. M. Wrate et al 622-627.

Foulds and Bedford hierarchy model: Comparative validation of the Foulds and Bedford hierarchy of psychiatric symptomatology; Leslie C. Morey 424-428.

General Health Questionnaire (GHQ): Prevalence of chronic psychiatric morbidity; Brian Stanley and Andrew J. Gibson 372-376.

General practice: Close encounters in general practice: experiences of a psychotherapy liaison team; Stephen Wilson and Katherine Wilson 277-281.

Gilles de la Tourette syndrome: Gilles de la Tourette syndrome and mania in an adolescent; A. Bleich et al (Brief report) 664-665.

Grief: Bereavement; Colin Murray Parkes (Review Article) 11-17.

Group therapy: Cognitive behavioural group treatment of bulimia; John A. Schneider and W. Stewart Agras 66-69.

Hallucinations: Subcultural delusions and hallucinations. Comments on the Present State Examination in a multicultural context; L. Swartz et al 391-394.

Haloperidol: Plasma cortisol levels in mania: associated clinical ratings and changes during treatment with haloperidol; J. C. Cookson et al 498-502.
Health priorities: More and more is less and less; the myth of massive psychiatric need; Alex Richman and Arthur Barry 164-168.

Hereditary factors: Hereditary differentiation of anxiety and affective neuroses; Svenn Torgersen 530-534.

Histrionic personality disorder: Clinical judgements of self-dramatisation: a test of the sexist hypothesis; P. R. Slavney and G. A. Chase 614-617.

Hive system, The: Hive system: a model for a psychiatric service; Peter Tyrer (Annotation) 571-575.

Homicide: Homicide in a psychiatric insititution; Jiři Modestin and Wolfgang Böker (Brief report) 321322.

Hospitalisation and Hospitals:

Alternatives to psychiatric hospitalisation; Digby Tantam (Annotation) 1-4.

Behaviour and skills of severely retarded adults in hospitals and small residential homes; Sally Rawlings 358-366.

Denial of the institution. A critical review of Franco Basaglia's writings; Raffaello Papeschi 247-254.

Homicide in a psychiatric institution; Jiří Modestin and Wolfgang Böker (Brief report) 321-322.

Institutionalisation and the outcome of functional psychoses; Eve C. Johnstone et al 36-44.

Suicide in hospital; Timothy Garvey (C) 101

Understanding the Italian experience; Kathleen Jones and Alison Poletti 341-347.

Hundred years ago, A: Broadmoor Asylum; Henry R. Rollin 458.

Training for asylum attendants; Henry R. Rollin 228 .

Huntington's chorea: Huntington's chorea without dementia: a problem case; T. H. Turner (Brief report) $548-550$.

Hypnotics: Zopiclone: a non-benzodiazepine hypnotic. Controlled comparison to temazepam in insomnia; David Wheatley 312-314.

Hyperventilation: Diagnostic issues in the hyperventilation syndrome; Christopher Bass and William Gardner (C) 101-102.

Hypochondriasis: Dysmorphophobia or monosymptomatic hypochondriasis?; Christopher S. Thomas (C) $672-673$

Hysteria: Investigation of hysteria using the Illness Behaviour Questionnaire; J. Wilson-Barnett and M. R. Trimble 601-608.

Illness Behaviour Questionnaire: Investigation of hysteria using the Illness Behaviour Questionnaire; J. WilsonBarnett and M. R. Trimble 601-608.

Imaging: Nuclear magnetic resonance (NMR): I. Imaging biochemical change: L. M. Eastwood et al 26-31. II. Imaging in dementia; J. A. O. Besson et al 31-35.

Infanticide: Attempted infanticide; A. J. Wilkins (Brief report) 206-208.

Inhibition: Mechanism to inhibit input activation and its dysfunction in schizophrenia; J. David Johnson 429435.

Insanity: Was insanity on the increase? T. H. Turner (C) 325 . 
Insomnia: Zopiclone: a non-benzodiazepine hypnotic. Controlled comparison to temazepam in insomnia; David Wheatley 312-314.

Institutionalisation and Institutions see Hospitalisation and Hospitals.

Intensive care: Psychiatric intensive care unit; Robert Goldney et al 50-54. Jeffrey Royle Jones (C) 561562.

Italy: Denial of the institution. A critical review of Franco Basaglia's writings; Raffaello Papeschi 247-254.

Understanding the Italian experience; Kathleen Jones and Alison Poletti $341-347$

Koro: Koro; Malcolm P. I. Weller (C) 452.

Koro in non-Chinese subjects; Robin A. Emsley

(C) 102. P. Moodly (C) 102-103. J. J. Bradley (C) 560

Language: Language in dementia: Robert E. Kuttner (C) $211-212$.

Language in schizophrenia. The stucture of monologues and conversations; D. R. Rutter 399-404.

Lateralisation: Stable abnormalities in the lateralisation of early corticol somatosensory evoked potentials in schizophrenic patients; J. E. Cooper et al 585-593.

Lectures: "The other half of medicine" and St Bartholomew's Hospital; Anthony W. Clare 120 126.

Needs of young intellectually retarded adults; F. S. W. Brimblecombe (18th Blake Marsh lecture. February 1984) 5-10.

Leicester: Leicester $E C T$ trial: results in schizophrenia; $S$. Brandon et al 177-183.

Lithium: Changes in the diagnoses of the functional psychoses associated with the introduction of lithium; Gordon Parker et al 377-382.

Impact of lithium in South-west Scotland. I. Demographic and clinical findings; R. G. McCreadie and D. P. Morrison 70-74. II. Longitudinal study; D. P. Morrison and R. G. McCreadie 74-77. III. Discontinuation of lithium; R. G. McCreadie et al 77-80.

Neuroleptics, lithium and renal function; Derek G. Waller et al 510-514.

Use of lithium in severely demented patients with behavioural disturbance; Anthony Holton and Kuruvilla George (C) 99-100.

Males: Multiaxial classification of male sexual dysfunction: Otto Benkert et al 628-632.

Mania: Gilles de la Tourette syndrome and mania in an adolescent; A. Bleich et al (Brief report) 664-665.

Is mania incompatible with Down's syndrome? Robert Sovner et al (Brief report) 319-320.

Plasma cortisol levels in mania: associated clinical ratings and changes during treatment with haloperidol; J. C. Cookson et al 498-502.

Manic-depressive psychoses: Institutionalisation and the outcome of functional psychosis: Eve C. Johnstone et al $36-44$.
Manual of Instruction of Attendants on the Insane: A Hundred Years Ago; Henry R. Rollin 228.

Marriage: Marital adjustment and treatment outcome in agoraphobia; W. Monteiro et al 383-390.

Psychological profile of the spouse of the female agoraphobic patient: personality and symptoms; William A. Arrindell and Paul M. G. Emmelkamp 405415.

Relationship between scores on Ryle's marital patterns test and independent ratings of marital quality; John Birtchnell 638-644.

Mating, assortative: Mates of schizophrenic mothers: a study of assortative mating from the American-Danish high risk project; Joseph Parnas 490-497.

Medicine: "The other half of medicine" and St Bartholomew's Hospital; Anthony W. Clare (Lecture) 120-126.

Medicine, traditional: Maggot in the salt, the snake factor and the treatment of atypical psychosis in West African women; Anne E. Farmer and Wojciech F. Falkowski (Brief report).

Mental disorders: Academic difficulty among male Egyptian University students; A. Okasha et al 140150.

Denial of the institution. A critical review of Franco Basaglio's writings; Raffaello Papeschi 247-254.

Fusarial mycotoxins and behaviour: possible implications for psychiatric disorder; R. Schoental (Annotation) 115-119.

Oral contraception and serious psychiatric illness: absence of an association; M. P. Vessey et al 45-49.

Study of 250 patients referred to a department of psychiatry for the deaf; John C. Denmark 282-286.

Water intoxication in psychiatric patients; Satnam Singh et al 127-131. Correction 562.

X-ray departments and psychiatry; E. P. Larkin 62-65.

Mental retardation: Behaviour and skills of severely retarded adults in hospitals and small residential homes; Sally Rawlings 358-366.

Needs of young intellectually retarded adults; F. S. W. Brimblecombe (18th Blake Marsh lecture, February 1984) 5-10.

Pipothiazine palmitate in the management of aggressive mentally handicapped patients; D. M. Lynch et al 525-529.

Young intellectually retarded adults; C. H. Nevill-Smith (C) 559 .

Mood changes: Mood changes after childbirth; Kenneth C. M. Wilson (C) 215-216.

Monoamine Oxidase (MAO): Present status of Monoamine Oxidase inhibitors; C. M. B. Pare (Review article) 576-584.

Toward a biochemical classification of depressive disorders IX: DST results and platelet MAO activity; Alan F. Schatzberg et al 633-637.

Morbidity Academic difficulty among male Egyptian students: I. Association with psychiatric morbidity; A. Okasha et al 140-144.

Depressive illness and morbid distress. Onset and development data examined against five-year outcome; J. R. M. Copeland 297-307. 
Prevalence of chronic psychiatric morbidity: a community sample; Brian Stanley and Andrew J. Gibson 372376.

Mothers: Mates of schizophrenic mothers: a study of assortative mating from the American-Danish high risk project; Josef Parnas 490-497.

Risk of child abuse among mothers who attempt suicide; Keith Hawton et al 486-489.

Mutism: Comparison of elective mutism and emotional disorders in children; Robert Wilkins 198-203.

Mycotoxins: Fusarial mycotoxins and behaviour: possible implications for psychiatric disorder; R. Schoental (Annotation) 115-119.

Naloxone: Initiated etorphine and naloxone binding to opioid receptors in caudate nucleus in schizophrenia; $F$. Owen et al 507-509.

Neuroleptic malignant syndrome: Aftercare of the patient with the neuroleptic malignant syndrome; Dov Aizenberg et al (Brief report) 317-318.

Neuroleptics: Neuroleptics, lithium and renal function; Derek G. Waller et al 510-514.

Neuroleptic serum levels measured by radioreceptor assay in patients receiving intramuscular depot neuroleptics. Some preliminary findings; John Turbott et al (Brief report) 439-442.

Schizophrenia with good and poor outcome. I. Early clinical features, response to neuroleptic and signs of organic dysfunction; T. Kolakowska et al 229-239.

Neuroses: Follow-up study of accident neurosis; Michael J. Tarsh and Claire Royston 18-25.

Neurotic patients who terminate their own treatment; Howard Roberts (Brief report) 442-445.

Nigeria: Brain-fag syndrome in Nigeria: Cognitive deficits in an illness associated with study; Olufemi Morakinyo (Brief report) 209-210.

Nomenclature: Atheroma, infarction and dementia: need for a new name? B. Mahendra et al (C) 211.

Nottingham: Nottingham ECT study: double-blind comparison of bilateral, unilateral and simulated ECT in depressive illness; S. Gregory et al 520-524.

Nuclear Magnetic Resonance (NMR): I. Imaging biochemical change; L. M. Eastwood et al 26-31. II. Imaging in dementia; J. A. O. Besson et al 31-35.

Old age: Late paraphrenia; Raymond Levy and Mohsen Naguib (c) 451. Peter S. Grahame (C) 451-452.

Opiate dependence: British opiate addicts: An 11-year follow-up; David Cottrell et al (Brief report) 448-450.

Electrostimulation and opiate withdrawal; Margaret A. Patterson (C) 213.

Organic mental disorders: Organic delusions: phenomenology, anatomical correlations and review; Jeffrey $L$. Cummings 184-197.

Outcome see also Follow-up studies:

Depressive illness and morbid distress: onset and development data examined against five-year outcome; J. R. M. Copeland 297-307.

Institutionalisation and the outcome of functional psychoses: Eve C. Johnstone et al 36-44.
Long-term depot maintenance of chronic schizophrenic out-patients. III. Relapse postponement or relapse prevention? The implications for long-term outcome; D. A. Curson et al 469-474.

Marital adjustment and treatment outcome in agoraphobia; W. Monteiro et al 383-390.

Schizophrenia with good and poor outcome: I. Early clinical features, response to neuroleptics and signs of organic dysfunction; T. Kolakowska et al 229-239. II. Cerebral ventricular size and its clinical significance; $\mathbf{A}$. O. Williams et al 239-246. III. Neurological 'soft' signs, cognitive impairment and their clinical significance; T. Kolakowska et al 348-357.

Overdoses: Overdoses: explanations and attitudes in selfpoisoners and significant others; Diane James and Keith Hawton 481-485.

Repetition of self-poisoning and subsequent death in adolescents who take overdoses; Michael Goldacre and Keith Hawton 395-398.

Overvalued ideas: Disorders with overvalued ideas; Christopher S. Thomas (C) 215.

Overvalued ideas; John Spencer (C) 327.

Paraphrenia: Late paraphrenia; Raymond Levy and Mohsen Naguib (C) 451. Peter S. Grahame (C) 451-452.

Parasuicide see Suicide, attempted.

Patient compliance: Combined psychotherapy and pharmacotherapy for depression-the compliance variable; J. T. Condon (C) 670-671.

Long-term depot maintenance of chronic schizophrenic out-patients. II. The incidence of compliance problems, side-effects, neurotic symptoms and depression; D. A. Cursonet al 469-474.

Neurotic patients who terminate their own treatment; Howard Roberts (Brief report) 442-445.

Professional and non-professional intervention for highly anxious primiparous mothers; Bryanne Barnett and Gordon Parker 287-293.

Personalities: Psychological profile of the spouse of the female agoraphobic patient: personality and symptoms; William A. Arrindell and Paul M. G. Emmelkamp 405-415.

Personality disorders: Clinical judgements of selfdramatisation: a test of the sexist hypothesis; P. R. Slavney and G. A. Chase 614-617.

Law, psychiatry and womens' imprisonment: a sociological view; Pat Carlen 618-621.

Pharmacotherapy: Combined psychotherapy and pharmacotherapy for depression-the compliance variable; J. T. Condon (C) 670-671.

Pipothiazine: Pipothiazine palmitate in the management of aggressive mentally handicapped patients; D. M. Lynch et al 525-529.

Pisa syndrome: Pisa syndrome: report of two cases: Ramzy Yassa (Brief report) 93-95.

Plasma: Plasma cortisol levels in mania: associated clinical ratings and changes during treatment with haloperidol; J. C. Cookson et al 498-502. 
Polydipsia: Medical and psychological investigation of psychogenic polydipsia: a case study; J. Kulkarni et al (Brief report) 545-547.

Prejudice, sexist: Clinical judgements of selfdramatisation: a test of the sexist hypothesis; P. R. Slavney and G. A. Chase 614-617.

Present State Examination (PSE): Epileptic psychosis: an evaluation of PSE profiles; M. M. Perez et al 155-163.

Subcultural delusions and hallucinations. Comments on the Present State Examination in a multi-cultural context; L. Swartz et al 391-394.

Primiparae: Professional and non-professional intervention for highly anxious primiparous mothers; Bryanne Barnett and Gordon Parker 287-293.

Prisons: Law, psychiatry and women's imprisonment: a sociological view; Pat Carlen 618-621.

Prognosis: Predicting improvement in patients with nonendogenous depression; Gordon Parker et al 132139.

'Pseudo-AIDS': 'Pseudo-AIDS' syndrome following from fear of AIDS; David Miller et al (Brief report) 550551.

Psychiatric disorders, illness and patients see Mental disorders.

Psychiatry: More and more is less and less: the myth of massive psychiatric need; Alex Richman and Arthur Barry 164-168.

Psychiatry in jeopardy? Steve Green and Chris Sage (C) 671 .

Social anthropology in relation to psychiatry; Roland Littlewood (Reading about ...) 552-554.

"The other half of medicine" and St Bartholomew's Hospital; Anthony W. Clare (Lecture) 120-126.

$X$-ray departments and psychiatry; E. P. Larkin 62-65.

Psychomotor disorders: Speech pause time as a method for the evaluation of psychomotor retardation in depressive illness; G. M. A. Hoffmann et al 535-538.

Psychoses: Biological antogonism and epileptic psychosis; P. Wolf and M. R. Trimble 272-276.

Changes in the diagnoses of the functional pyschoses associated with the introduction of lithium; Gordon Parker et al 377-382.

Epileptic psychosis: evaluation of P.S.E. profiles; M. M. Perez et al 155-163.

Institutionalisation and the outcome of functional psychoses; Eve C. Johnstone et al 36-44.

Is there really a schizophrenia? The long-term course of psychotic phenomena; Luc Ciompi (C) 558-559.

Maggot in the salt, the snake factor and the treatment of atypical psychosis in West African women; Anne E. Farmer and Wojciech F. Falkowski (Brief report) $446-448$.

Nuclear Magnetic Resonance (NMR). I. Imaging biochemical change; L. M. Eastwood et al 26-31.

Psychotherapy: Close encounters in general practice: experiences of a psychotherapy liaison team; Stephen Wilson and Katherine Wilson 277-281.

Combined psychotherapy and pharmacotherapy for depression-the compliance variable; J. T. Condon (C) $670-671$.
Psychotherapy and psychiatric need; Michael Hunt (C) 669-670.

What price psychotherapy? a rejoinder; Sidney Bloch and Michael J. Lambert (Comments) 96-98. Michael Shepherd (Discussion) 555-556. H. J. Eysenck (Discusion) 556-557.

Questionnaires see also Present State Examination:

Chronicity and the General Health Questionnaires M. E. Goodchild and Paul Duncan-Jones 55-61.

Investigation of hysteria using the Illness Behaviour Questionnaire; J. Wilson-Barnett and M. R. Trimble 601-608.

Relationship between scores on Ryle's Marital Patterns Test and independent ratings of marital quality; John Birtchnell 638-644.

Radioreceptor assay: Neuroleptic serum levels measured by radioreceptor assay in patients receiving intramuscular depot neuroleptics. Some preliminary findings; John Turbott et al (Brief report) 439-442.

Reading about . . .. Social anthropology in relation to psychiatry; Roland Littlewood 552-554.

Relaxation: Relaxation and depersonalisation; Jack D. Edinger (C) 103.

Renial function: Neuroleptics, lithium and renal function; Derek G. Waller et al 510-514.

Residential treatment: Behaviour and skills of severely retarded adults in hospitals and small residential homes; Sally Rawlings 358-366.

Retroviruses: Lack of evidence for retrovirus infection in schizophrenic patients; Lynn E. DeLisi and Prem S. Sarin (C) 674. T. G. Crow (C) 674-675.

Retroviruses and schizophrenia; Majorie Robert-Guroff et al (C) 326.

Review articles: Bereavement; Colin Murray Parkes 1117.

Present status of Monoamine Oxidase inhibitors; C. M. B Pare 576-584.

Rivers, W. H. R.: Another Bart's alumnus: W. H. R. Rivers; Roland Littlwood (C) 559.

Ryle's Marital Patterns Test: Relationship between scores on Ryle's Marital Patterns Test and independent ratings of marital quality; John Birtchnell 638-644.

St Bartholomew's Hospital: "The other half of medicine" and St Bartholomew's Hospital (Lecture) 120-126.

Another Bart's alumnus: W. H. R. Rivers; Roland Littlewood (C) 559.

Schizophrenia: Biological antagonism and epileptic psychosis; P. Wolf and M. R. Trimble 272-276.

Changes in the diagnoses of the functional psychoses associated with the introduction of lithium; Gordon Parker et al 377-382.

CT scans in schizophrenia; Michael A. Reveley 367371.

Controlled trial of social intervention in the families of schizophrenic patients: two year follow-up; Julian Leff et al $594-600$. 
Cytomegalovirus and schizophrenia: a test of a viral hypothesis; Satish Shrikhande et al 503-506.

Decline in the diagnosis of schizophrenia among first admissions to Scottish mental hospitals from 1969-78; John M. Eagles and Lawrence J. Whalley 151-154.

Did Shakespeare know schizophrenia? The case of poor mad Tom in King Lear; Nigel M. Bark (Comments) $436-438$.

Eating disorders in schizophrenia; G. C. Lyketsos et al 255-261.

Erotomania in Schneider-positive schizophrenia: a case report; Mary Hayes and Brian O'Shea (Brief report) 661-663.

Falling incidence of schizophrenia? Shôn Lewis (C) $560-561$.

Institutionalisation and the outcome of functional psychoses; Eve C. Johnstone et al 36-44.

Is there really a schizophrenia? the long-term course of psychotic phenomena; Luc Ciompi (C) 558-559. Atul C. Pande (C) 675.

Lack of evidence for retrovirus infection in schizophrenic patients; Lynn E. DeLisi and Prem S. Sarin (C) 674. T. J. Crow (C) 674-675.

Language in schizophrenia. The structure of monologues and conversation; D. R. Rutter 399-404.

Late paraphrenia; Raymond Levy and Mohsen Naguib (C) 451. Peter S. Grahame (C) 451-452.

Leicester ECT trial: results in schizophrenia; S. Brandon et al 177-183.

Long-term depot maintenance of chronic schizophrenic out-patients: The seven year follow-up of the Medical Research Council fluphenazine/placebo trial; D. A. Curson et al 464-480.

Mates of schizophrenic mothers: a study of assortative mating from the American-Danish high risk project; Josef Parnes 490-497.

Mechanism to inhibit input activation and its dysfunction in schizophrenia; J. David Johnson 429-435.

Motor and sighting dominance in schizophrenia and affective disorder; Edward L. Merrin 539-544.

Neuroleptic serum levels measured by radioreceptor assay in patients receiving intramuscular depot neuroleptics. Some preliminary findings; John Turbott et al (Brief report) 439-442.

Retroviruses and schizophrenia; Majorie Robert-Guroff et al (C) 326.

Schizophrenia with good and poor outcome: I. Early clinical features, response to neuroleptics and signs of organic dysfunction; T. Kolakowska et al 229-239. II. Cerebral ventricular size and its clinical significance; $\mathbf{A}$. O. Williams et al 239-246. III. Neurological 'soft' signs, cognitive impairment and their clinical significance; T. Kolakowska et al 348-357.

'Stuck synapse' as a model for schizophrenia; G. Neil Conacher (C) 672.

Stable abnormalities in the lateralisation of early cortical somatosensory evoked potentials in schizophrenic patients; J. E. Cooper et al 585-593.
Tritiated etorphine and naloxone binding to opioid receptors in caudate nucleus in schizophrenia; F. Owen et al 507-509.

Was insanity on the increase? T. H. Turner (C) 325.

Sex disorders: Multiaxial classification of male sexual dysfunction; Otto Benkert et al 628-632.

Scotland: Decline in the diagnosis of schizophrenia among first admissions to Scottish mental hospitals from 196978; John M. Eagles and Lawrence J. Whalley 151154.

Impact of lithium in South-west Scotland. I. Demographic and clinical findings; R. G. McCreadie and D. P. Morrison 70-80. II. Longitudinal study; D. P. Morrison and R. G. McCreadie 74-77. III. Discontinuation of lithium; R. G. McCreadie et al 77-80.

Seizures: Spontaneous seizures after ECT; Walter F. Daniel (C) 100-101.

Self-poisoning: Overdoses: explanations and attitudes in self-poisoners and significant others; Diane James and Keith Hawton 481-485.

Repetition of self-poisoning and subsequent death in adolescents who take overdoses; Michael Goldacre and Keith Hawton 395-398.

Shakespeare, W.: Did Shakespeare know schizophrenia? The case of poor mad Tom in King Lear; Nigel M. Bask (Comments) 436-438.

Siblings: Pairs of same-sexed siblings discordant for antisocial behaviour; Marge Reitsma-Street et al 415423.

Significant others: Overdoses: explanations and attitudes in self-poisoners and significant others; Diane James and Keith Hawton 481-485.

Social work: Controlled trial of social intervention in the families of schizophrenic patients: two year follow-up; Julian Leff et al 594-600.

Professional and non-professional intervention for highly anxious primiparous mothers; Bryanne Barnett and Gordon Parker 287-293.

'Son' signs: Schizophrenia with good and poor outcome. III. Neurological 'soft' signs, cognitive impairment and their clinical significance; T. Kolakowska et al 348357.

Spouse: Psychological profile of the spouse of the female agoraphobic patient: personality and symptoms; William A. Arrindell and Paul M. G. Emmelkamp 405415.

Stengel, Erwin: Eric and Erwin: let's get it right; Seymour Spencer (C) 675 .

Strauss, Eric: Eric and Erwin: let's get it right; Seymour Spencer (C) 675.

Stress disorders, post-traumatic: Emotional consequencies of ejection, rescue and rehabilitation in Royal Air Force aircrew; D. C. Fowlie and M. O. Aveline 609-613.

Students: Academic difficulty among male Egyptian University students. I. Association with psychiatric morbidity 140-144. II. Associations with demographic and psychological factors; Ahmed Okasha et al $144-150$. 
Brain-fag syndrome in Nigeria: cognitive deficits in an illness associated with study; Olufemi Morakinyo (Brief report) 209-210.

Suicide: Suicide and parasuicide in childhood and early adolescence; Donald J. Brooksbank (Annotation) $459-463$.

Suicide in hospital; Timothy Garvey (C) 101.

Suicide, attempted: Overdoses: explanations and attitudes in self-poisoners and significant others; Diane James and Keith Hawton 481-485.

Risk of child abuse among mothers who attempt suicide; Keith Hawton et al 486-489.

Suicide and parasuicide in childhood and early adolescence; Donald J. Brooksbank (Annotation) 459-463.

Sulpiride: Early clinical experiences with sulpiride; Som D. Soni and H. L. Freeman (C) 673.

Symptoms: Comparative validation of the Foulds and Bedford hierarchy of psychiatric symptomatology; Leslie C. Morey 424-428.

Synapses: 'Stuck synapse' as a model for schizophrenia; G. Neil Conacher (C) 672 .

Teetotallism: Why teetotallers abstain; Jennifer Hughes $e t$ al (Brief report) 204-206.

Temazepam: Zopiclone: a non-benzodiazepine hypnotic. Controlled comparison to temazepam in insomnia; David Wheatley 312-314.

Vampirism: Vampirism-a clinical condition; Herschel Prins (Comments) 666-668.

Verbal behaviour: Speech pause time as a method for the evaluation of psychomotor retardation in depressive illness; G. M. A. Hoffmann et al 535-538.

Wards of Court: Examining children who are Wards of Court; Jason Maratos (C) 216.

Water intoxication: Water intoxication in psychiatric patients; Satnam Singh et al 127-131. (Correction) 562.

X-rays: X-ray departments and psychiatry; E. P. Larkin 62-65.

Value of routine X-rays in dementia; E. B. Renvoize et al (C) 560

Zopiclone: Zopiclone: a non-benzodiazepine hynotic. Controlled comparison to temazepam in insomnia; David Wheatley 312-314.

Women's imprisonment: Law, psychiatry and women's imprisonment: a sociological view; Pat Carlen 618621 .

\section{PART II-CONTRIBUTORS}

Abrams, Richard See Taylor, Michael Alan Agras, W. Stewart See Schneider, John A.
Aizenberg, Dov, Shalev, Arieh and Munitz, Hanan The aftercare of the patient with the neuroleptic malignant syndrome (Brief report) 317

Anderson, A. A. See Lynch, D. M.

Andrews, Gavin See Moran, Carmen

Andrews, H. See Cooper, J. E.

Apter, A. See Bleich, A.

Ardern, M. See Kolakowska, T.

See Williams, A. O.

Arrindell, Willem A. and Emmelkamp, Paul M. G. Psychological profile of the spouse of the female agoraphobic patient; personality and symptoms 405

Ashcroft, G. W. See Besson, J. A. O.

Ashour, A. See Okasha, A.

Aveline, M. O. See Fowlie, D. G.

Bamber, R. W. See Curson, D. A.

Barber, C. See Cooper, J. E.

Bark, Nigel M. Did Shakespeare know schizophrenia?

The case of poor mad Tom in King Lear 436

Barnes, T. R. E. See Curson, D. A.

Barnett, Bryanne and Parker, Gordon Professional and non-professional intervention for highly anxious primiparous mothers 287

Barraclough, Brian See Hughes, Jennifer

Barry, Arthur See Richman, Alex

Bass, Christopher (C) 101

Bearn, Jennifer (C) 214

Beis, A. See Lyketsos, G. C.

Ben-Arie, 0. See Swartz, L.

Benkert, Otto, Maier, Wolfgang and Holsboer, Forian Multiaxial classification of male sexual dysfunction 628

Berkowitz, Ruth See Leff, Julian

Bernout, E. See Bleich, A.

Besser, G. M. See Cookson, J. C.

Besson, J. A. O., Corrigan, F. M., Foreman, E. Iljon, Eastwood, L. M., Smith, F. W. and Ashcroft, G. W. Nuclear magnetic resonance (NMR). II. Imaging in dementia 31

See Eastwood, L. M.

Birtchnell, John The relationship between scores on Ryle's marital patterns test and independent ratings of marital quality 638

Bishry, Z. See Okasha, A.

Bleich, A., Bernout, E., Apter, A. and Tyano, S. Gilles de la Tourette syndrome and mania in an adolescent (Brief report) 664

Blignault, Ilse See Parker, Gordon

Bloch, Sidney and Lambert, Michael, J. What price psychotherapy? A rejoinder (Comments)

Böker, Wolfgang See Modestin, Jiř́

Boulenger, Jean-Philippe See Silberman, Edward K.

Bourne, R. C. See Owen, F.

Bowes, Julia See Goldney, Robert

Bradley, J. J. (C) 560

Brandon, S., Cowley, P., McDonald, C., Neville, P., Palmer, R. and Wellstood-Eason, S. Leicester ECT trial: results in schizophrenia 177

Brimblecombe, F.S. W. The needs of young intellectually retarded adults (18th Blake Marsh Lecture) 5 
Brooksbank, Donald J. Suicide and parasuicide in childhood and early adolescence 459

Bullard, Henrietta See Singh, Satnam

Calvert, Louie M. See Johnstone, Eve C.

Carlen, Pat Law, psychiatry and women's imprisonment. A sociological view 618

Carroll, Gillian See Miller, David

Chase, G. A. See Slavney, P. R.

Checkley, S. A. See Robinson, P. H.

Childs-Clarke, Adrian See Cottrell, David

Ciompi, Luc (C) 558

Cooper, J. E., Andrews, H. and Barber, C. Stable abnormalities in the lateralisation of early cortical somatosensory evoked potentials in schizophrenic patients 585

Copeland, J. R. M. Depressive illness and morbid distress. Onset and development data examined against five-year outcome 297

Coppen, Alec, Milln, Philip, Harwood, Janet and Wood, Keith Does the dexamethasone suppression test predict antidepressant treatment success? 294

Corrigan, F. M. See Besson, J. A. O.

Czechowicz, Andrew See Goldney, Robert

Clare, Anthony W. "The other half of medicine" and St. Bartholomew's Hospital (Lecture) 120

Coleman, J. C. See Shrikhande, Satish

Conacher, G. Neil (C) 672

Condon, J. T. (C) 670

Cookson, J. C., Silverstone, T., Williams, S. and Besser, G. M. Plasma cortisol levels in mania: associated clinical ratings and changes during treatment with haloperidol 498

Copolov, D. See Kulkarni, J.

Cottrell, David, Childs-Clarke, Adrian and Ghodse, A. Hamid British opiate addicts: an 11-year follow-up (Brief report) 448

Cowley, P. See Brandon, S.

Cox, J. L. See Wrate, R. M.

Crow, T. J. (C) 674

- See Owen, F.

Cummings, Jeffrey L. Organic delusions: phenomenology, anatomical correlations, and review 184

Curson, D. A., Barnes, T. R. E., Bamber, R. W., Platt, S. D., Hirsch, S. R. and Duffy, J. C. Long-term depot maintenance of chronic schizophrenic out-patients: The seven year follow-up of the Medical Research Council fluphenazine/placebo trial. I. Course of illness, stability of diagnosis and the role of a special maintenance clinic. II. The incidence of compliance problems, side-effects, neurotic symptoms and depression. III. Relapse postponement or relapse prevention? The implications for long-term outcome 464

Daly, Joan See O'Connor, Art

Daniel, Walter, F. (C) 100

Dayton, R. See Shrikhande, Satish

DeLisi, Lynn E. (C) 674

Denmark, John, C. A study of 250 patients referred to a department of psychiatry for the deaf 282
Duffy, J. C. See Curson, D. A.

Duncan-Jones, Paul See Goodchild, M. E.

Eagles, John M. and Whalley, Lawrence J. Decline in the diagnosis of schizophrenia among first admissions to Scottish mental hospitals from 1969-78 151

Eastwood, L. M., Hutchison, J. M. S. and Besson, J. A. O. Nuclear magnetic resonance (NMR): I. Imaging biochemical change 26

- See Besson, J. A. O.

Edinger, Jack D. (C) 103

Edwards, J. Guy See Waller, Derek G.

Eliatamby, C. L. S. See Lynch, D. M

Ellis, Peter and Mellsop, Graham De Clérambault's syndrome-a nosological entity? (Brief report) 90

Emmelkamp, Paul M. G. See Arrindell, Willem A.

Emsley, Robin A. (C) 102

Eysencck, H. J. (C) What price psychotherapy? (Discussion) 556

Falkowski, Wojciech See Farmer, Anne E

Faraone, Stephen V. See Tsuang, Ming T.

Farmer, Anne E. and Falkowski, Wojciech F. Maggot in the salt, the snake factor and the treatment of atypical psychosis in West African Women (Brief report) 446

Farmer, Roger. See Miller, David

Feinberg, Shalom (C) 103

Fernando, F. P. and Frieze, M. A relapsing folie à trois (Brief report) 315

Finch, Terri See Reitsma-Street, Marge

Fleming, Jerome A. See Tsuang, Ming T.

Foreman, E. Iljon See Besson, J. A. O.

Fowlie, D. G. and Aveline, M. O. The emotional consequences of ejection, rescue and rehabilitation in Royal Air Force aircrew 609

Freeman, Hugh See Singh, Satnam

Frieze, M. See Fernando, F. P.

Frith, C. D. See Johnstone, Eve C.

Gagiano, C. A. (C) 452

Garvey, Timothy (C) 101

Gelder, M. G. See Kolakowska, T.

Gerson, Benjamin See Schatzberg, Alan F.

Ghodse, A. Hamid See Cottrell, David

Gibson, Andrew J. See Stanley, Brian

Gill, D. See Gregory, S.

Goldacre, Michael and Hawton, Keith Repetition of selfpoisoning and subsequent death in adolescents who take overdoses 395

Goldney, Robert, Bowes, Julia, Spence, Neil, Czechowicz, Andrew and Hurley, Rod The psychiatric intensive care unit 50

Gonze, J. C. See Hoffmann, G. M. A.

Goodchild, M. E. and Duncan-Jones, Paul Chronicity and the General Health Questionnaire 55

Goodwin, Guy See Hawton, Keith

Grahame, Peter S. (C) 451

Green, John See Miller, David

Green, Steve (C) 671 
Gregory, S., Shawcross, C. R. and Gill, D. The Nottingham ECT study: a double-blind comparison of bilateral, unilateral and simulated ECT in depressive illness 520

Harwood, Janet See Coppen, Alec

Hawley, Richard M. The outcome of anorexia nervosa in younger subjects 657

Hawton, Keith, Roberts, Jacqueline and Goodwin, Guy The risk of child abuse among mothers who attempt suicide 486

- See Goldacre, Michael, James, Diane

Hayes, Mary and O'Shea, Brian Erotomania in Schneider-positive schizophrenia. A case report. (Brief report) 661

Hirsch, S. R. See Curson, D. A

See Shrikhande, Satish

Hoffmann, G. M. A., Gonze, J. C. and Mendlewicz, J. Speech pause time as a method for the evaluation of psychomotor retardation in depressive illness $\mathbf{5 3 5}$

Holloway, Frank (C) 104

Holsboer, Florian See Benkert, Otto

Holton, Anthony (C) 99

Hughes, Jennifer, Stewart, Murray and Barraclough, Brian Why teetotallers abstain. (Brief report) 204

Hunt, Michael (C) 669

Hunter, Lynley See Turbott, John

Hurley, Anne Desnoyers See Sovner, Robert

Hurley, Rod See Goldney, Robert

Hutchison, J. M. S. See Eastwood, L. M.

Imlah, Norman $\mathbf{W}$. An evaluation of alprazolam in the treatment of reactive or neurotic (secondary) depression 515

Jambor, K. See Kolakowska, T.

James, Diane and Hawton, Keith Overdoses: Explanations and attitudes in self-poisoners and significant others 481

Jenike, Michael A. (C) 326

Johnson, J. David A mechanism to inhibit input activation and its dysfunction in schizophrenia 429

Johnstone, Eve C., Owens, D. G. C., Frith, C. D. and Calvert, Louie M. Institutionalisation and the outcome of functional psychoses 36

Johnstone, Eve C. (C) Correction 216

Jones, Jefirey Royle (C) 561

Jones, Kathleen and Poletti, Alison Understanding the Italian experience 341

Kamel, M. See Okasha, A.

Khalil, A. H. See Okasha, A.

Kolakowska, T., Williams, A. O., Ardern, M., Reveley, M. A., Jambor, K., Gelder, M. G. and Mandelbrote, B. M. Schizophrenia with good and poor outcome. I: Early clinical features, response to neuroleptics and signs of organic dysfunction 229

Jambor, K. and Ardern, M. Schizophrenia with good and poor outcome. III. Neurological 'soft' signs, cognitive impairment and their clinical significance 348
Kolakowska, T. See Williams, A. O

Kosterlitz, H. W. See Owen, F.

Kuipers, Liz See Leff, Julian

Kulkarni, J., McLachlan, R. and Copolov, D. The medical and psychological investigation of psychogenic polydipsia: a case study (Brief report) 545

Kuttner, Robert E. (C) 211

Labrie, Richard See Sovner, Robert

Lambert, Michael J. See Bloch, Sidney

Larkin, E. P. The X-ray department and psychiatry 62

Lawless, M. See Vessey, M. P.

Leff, Julian, Kuipers, Liz, Berkowitz, Ruth and Sturgeon, David A controlled trial of social intervention in the families of schizophrenic patients: two year followup 594

Lerbinger, Jan E. See Schatzberg, Alan F.

Levy, Raymond (C) 451

Lewis, Shôn (C) 560

Lishman, W. A. (C) 99

Littlewood, Roland Reading about . . . Social anthropology in relation to psychiatry 552

- (C) 559

Lotaif, F. See Okasha, A.

Lowe, M. R. (C) 558

Lyketsos, G. C., Paterakis, P., Beis, A. and Lyketsos, C. G. Eating disorders in schizophrenia 255

Lyketsos, C. G. See Lyketsos, G. C.

Lynch, D. M., Eliatamby, C. L S. and Anderson, A. A. Pipothiazine palmitate in the management of aggressive mentally handicapped patients 525

McCormick, M. See McCreadie, R. G.

McCreadie, R. G. and Morrison, D. P. The impact of lithium in South-west Scotland. I. Demographic and clinical findings 70

- McCormick, M. and Morrison, D. P. The impact of lithium in South-west Scotland. III. The discontinuation of lithium 77

See Morrison, D. P.

McDonald, C. See Brandon, S.

McLachlan, R. See Kulkarni, J.

McPherson, K. See Vessey, M. P.

Mahendra, B. (C) 211

Maier, Wolfgang See Benkert, Otto

Mandelbrote, B. M. See Kolakowska, T.

-See Williams, A. O.

Maratos, Jason (C) 216

Marks, I. M. See Monteiro, W.

Mellsop, Graham See Ellis, Peter

Mendlewicz, J. See Hoffmann, G. M. A.

Merrin, Edward L. Motor and sighting dominance in schizophrenia and affective disorder: evidence for right-hand grip strength prominence in paranoid schizophrenia and bipolar illness 539

Miller, David, Green, John, Farmer, Roger and Carroll, Gillian A 'pseudo-AIDS' syndrome following from fear of AIDS (Brief report) 550

Milin, Philip See Coppen, Alec

Mitchell, John (C) 669 
Modestin, Jirŕ and Böker, Wolfgang Homicide in a psychiatric institution (Brief Report) 321

Monteiro, W., Marks, I. M. and Ramm, E. Marital adjustment and treatment outcome in agoraphobia 383

Moodley, P. (C) 102

Morakinyo, Olufemi The brain-fag Syndrome in Nigeria; cognitive deficits in an illness associated with study (Brief Report) 209

Moran, Carmen and Andrews, Gavin The familial occurrence of agoraphobia 262

Morey, Leslie C. A comparative validation of the Foulds and Bedford hierarchy of psychiatric symptomatology 424

Morrison, D. P. and McCreadie, R. G. The impact of lithium in South-west Scotland. II. A longitudinal study 74

-See McCreadie, R. G.

Munitz, Hanan See Aizenberg, Dov

Munro, Alistair (C) 561

Murray, N. M. F. See Perez, M. M.

Neville, P. See Brandon, S.

Neville-Smith, C. H. (C) 559

Nurnberger, John See Silberman, Edward K.

O'Connor, Art and Daly, Joan Alcoholics: a twenty year follow-up study 645

O'Donnell, Maryanne and Parker, Gordon

Offord, David R. See Reitsma-Street, Marge

Okasha, A., Kamel, M., Khalil, A. H., Sadek, A. and Ashour, A. Academic difficulty among male Egyptian university students: I: Association with psychiatric morbidity 140

- Lotaif, F., Khalil, A. H. and Bishry, Z. Academic difficulty among male Egyptian university students. II. Associations with demographic and psychological factors 144

O'Shea, Brian See Hayes, Mary

Owen, F., Bourne, R. C., Poulter, M., Crow, T. J., Paterson, S. J. and Kosterlitz, H. W. Tritiated etorphine and naloxone binding to opioid receptors in caudate nucleus in schizophrenia 507

Owens, D. G. C. See Johnstone, Eve C.

Padi, Madhu H. See Singh, Satnam

Palmer, R. See Brandon, $S$.

Pande, Atul C. (C) 675

Papeschi, Rafiaello The denial of the institution. A critical review of Franco Basaglia's writings 247

Pare, C. M. B. The present status of monoamine oxidase inhibitors (Review Article) 576

Parker, Gordon, Tennant, Chris and Blignault, Ilse Predicting improvement in patients with non-endogenous depression 132

O'Donnell, Maryanne and Walter, Stephen Changes in the diagnoses of the functional psychoses associated with the introduction of lithium 377
- See Barnett, Bryanne

Parkes, Colin Murray Bereavement (Review Article) 11

Parnas, Josef Mates of schizophrenic mothers: A study of assortative mating from the American-Danish High Risk Project 490

Paterakis, P. See Lyketsos, G. C.

Paterson, S. J. See Owen, F.

Patterson, Margaret A. (C) 213

Perez, M. M., Trimble, M. R., Murray, N. M. F. and Reider, I. Epileptic psychosis: an evaluation of P.S.E. profiles 155

Platt, S. D. See Curson, D. A.

Polak, A. See Waller, Derek G

Poletti, Alison See Jones, Kathleen

Post, Robert M. See Silberman, Edward K.

Poulter, M. See Owen, F.

Prins, Herschel Vampirism-a cliical condition (Comments) 666

Rabins, Peter V. (C) 212

Ramm, E. See Monteiro, W.

Rawlings, Sally Behaviour and skills of severely retarded adults in hospitals and small residential homes 358

Reider, I. See Perez, M. M.

Reitsma-Street, Marge, Offord, David R. and Finch, Terri Pairs of same-sexed siblings discordant for antisocial behaviour 415

Renvoize, E. B. (C) 560

Reveley, Michael A. CT scans in schizophrenia 367

- See Kolakowska, T.

See Satish, Shrikhande.

See Williams, A. O.

Richman, Alex and Barry, Arthur More and more is less and less: the myth of massive psychiatric need 164

Robert-Guroff, Marjorie (C) 326

Roberts, Howard Neurotic patients who terminate their own treatment (Brief report) 442

Roberts, Jacqueline See Hawton, Keith

Robinson, P. H., Checkley, S. A. and Russell, G. F. M. Suppression of eating by fenfluramine in patients with bulimia nervosa 169

Rooney, A. C. See Wrate, R. M.

Rothschild, Anthony J. See Schatzberg, Alan F.

Roy-Byrne, Peter P. (C) 558

Royston, Claire See Tarsh, Michael J.

Russell, G. F. M. See Robinson, P. H.

Rutter, D. R. Language in schizophrenia: the structure of monologues and conversations 399

Sadek, A. See Okasha, A

Schatzberg, Alan, F., Rothschild, Anthony J., Gerson, Benjamin, Lerbinger, Jan E. and Schildkraut, Joseph J. Toward a biochemical classification of depressive disorders. IX. DST results and platelet MAO activity 633

Schildkraut, Joseph J. See Schatzberg, Alan F.

Schneider, John A. and Agras, W. Stewart A cognitive behavioural group treatment of bulimia 66 
Schoental, R. Fusarial mycotoxins and behaviour: possible implications for psychiatric disorder (Annotation) 115

Shalev, Arieh See Aizenberg. Dov

Shawcross, C. R. See Gregory, S.

Shepherd, Michael (C) What price psychotherapy? (Discussion) 555

Shrikhande, Satish, Hirsch, S. R., Coleman, J. C., Reveley, M. A. and Dayton, R. Cytomegalovirus and schizophrenia: A test of a viral hypothesis 503

Silberman, Edward K., Post, Robert M., Nurnberger, John, Theodore, William and Boulenger, Jean-Philippe Transient sensory, cognitive and affective phenomena in affective illness. A comparison with complex partial epilepsy 81

Silverstone, T. See Cookson. J. C.

Singh, Satnam, Padi, Madhu H., Bullard, Henrietta and Freeman, Hugh Water intoxication in psychiatric patients 127

Slavney, P. R. and Chase, G. A. Clinical judgements of self-dramatisation. A test of the sexist hypothesis 614

Smith, F. W. See Besson, J. A. O.

Soni, Som D. (C) 673

Sovner, Robert, Hurley, Anne Desnoyers and Labrie, Richard Is mania incompatible with Down's syndrome? (Brief report) 319

Spence, Neil See Goldney, Robert

Spencer, John (C) 327

Spencer, Seymour (C) 675

Stanley, Brian and Gibson, Andrew J. The prevalence of chronic psychiatric morbidity: A community sample 372

Stewart, Murray See Hughes. Jennifer

Sturgeon, David See Leff, Julian

Swartz, L., Ben-Arie, O. and Teggin, A. F. Subcultural delusions and hallucinations: Comments on the Present State Examination in a multi-cultural context 391

Szmukler, George I. See Thomas, Joseph P.

Tantam, Digby Alternatives to psychiatric hospitalisation 1

Tarsh, Michael J. and Royston, Claire A follow-up study of accident neurosis 18

Taylor, Michael, Alan and Abrams, Richard Short-term cognitive effects of unilateral and bilateral ECT 308

Taylor, Melanie (C) 214

Teggin, A. F. See Swartz, L.

Tennant, Chris See Parker, Gordon

Theodore, William See Silberman, Edward K.

Thomas, Christopher S. (C) 215, 672

Thomas, Joseph P. and Szmukler, George I. Anorexia nervosa in patients of Afro-Caribbean extraction 653

Thomas, P. F. See Wrate, R. M.

Thompson, Chris (C) 557

Torgersen, Svenn Hereditary differentiation of anxiety and affective neuroses 530

Trimble, M. R. See Perez, M. M., Wilson-Barnett, J., Wolf, P.
Tsuang, Ming T., Faraone, Stephen, V. and Fleming, Jerome A. Familial transmission of major affective disorders. Is there evidence supporting the distinction between unipolar and bipolar disorders? 268

Turbott, John, Villiger, John and Hunter, Lynley Neuroleptic serum levels measured by radioreceptor assay in patients receiving intramuscular depot neuroleptics: some preliminary findings (Brief report) 439

Turner, T. H. Huntington's Chorea without dementia: A problem case (Brief report) 548

(C) 325

Tyano, S. See Bleich, A.

Tyrer, Peter The hive system. A model for a psychiatric service (Annotation) 571

Vessey, M. P., McPherson, K., Lawless, M. and Yeates, D. Oral contraception and serious psychiatric illness: absence of an association 45

Villiger, John See Turbott, John

Waller, Derek G., Edwards, J. Guy and Polak, A. Neuroleptics, lithium and renal function 510

Walter, Stephen See Parker, Gordon

Weller, Malcolm P. I. (C) 452

Wellstood-Eason, S. See Brandon, S.

Whalley, Lawrence J. See Eagles, John M.

Wheatley, David Zopiclone: a non-benzodiazepine hypnotic. Controlled comparison to temazepam in insomnia 312

Wilkins, A. J. Attempted infanticide (Brief report) 206

Wilkins, Robert A comparison of elective mutism and emotional disorders in children 198

Williams, A. O., Reveley, M. A., Kolakowska, T., Ardern, M. and Mandelbrote, B. M. Schizophrenia with good and poor outcome. II: Cerebral ventricular size and its clinical significance 239

- See Kolakowska, T.

Williams, S. See Cookson, J. C.

Wilson, Katherine See Wilson, Stephen

Wilson, Kenneth C. M. (C) 215

Wilson, Stephen and Wilson, Katherine Close encounters in general practice: Experiences of a psychotherapy liaison team 277

Wilson-Barnett, J. and Trimble, M. R. An investigation of hysteria using the Illness Behaviour Questionnaire 601

Wolfe, P. and Trimble, M. R. Biological antagonism and epileptic psychosis 272

Wood, Keith See Coppen, Alec

Wrate, R. M., Rooney, A. C., Thomas, P. F. and Cox, J. L. Postnatal depression and child development. A three-year follow-up study 622

Yassa, Ramzy The Pisa syndrome: a report of two cases (Brief report) 93

Yeates, D. See Vessey, M. P.

Yellowlees, A. J. Anorexia and bulimia in anorexia nervosa: a study of psychosocial functioning and associated psychiatric symptomatology 648 


\section{PART II-BOOK REVIEWS ALCOHOL AND DRUG ABUSE}

Edwards, Griffith, Arif, Awni and Jafie, Jerome (Eds.): Drug Use and Misuse: Cultural Perspectives 328

Edwards, Griffith and Littleton, John (Eds.): Pharmacological Treatments for Alcoholism 227

Fehr, Kevin O'Brien and Kalant, Harold: Cannabis and Health Hazards: Proceedings of an ARF/WHO Scientific Meeting on Adverse Health and Behavioural Consequences of Cannabis Use 335

Galanter, Marc (Ed.): Recent Developments in Alcoholism. Volume 2: Learning and Social Models, Alcohol and the Liver, Ageing and Alcoholism, Anthropology 332

Grant, Marcus: Same Again: A Guide to Safer Drinking 456

Krasner, Neville, Madden, J. S. and Walker, Robin J. (Eds.): Alcohol Related Problems: Room for Manoeuvre 225

Macdonald, Donald Ian: Drugs, Drinking and Adolescents 218

Petursson, Hannes and Lader, Malcolm: Dependence on Tranquillizers 328

Rosett, Henry L. and Weiner, Lyn: Alcohol and the Fetus. A Clinical Perspective 677

Schuckit, MarcA.: Drug and Alcohol Abuse: A Clinical Guide to Diagnosis and Treatment. 2nd Edition 333

\section{BEREAVEMENT}

Parkes, Colin Murray and Weiss, Robert S.: Recovery from Bereavement 680

\section{CHILDREN, ADOLESCENTS AND FAMILIES}

Bernstein, Norman R. and Sussex, James (Eds.): Handbook of Psychiatric Consultation with Children and Youth 568

Chess, Stella and Thomas, Alexander (Eds.): Annual Progress in Child Psychiatry and Child Development 1983225

Davis, Madeleine and Wallbridge, David (Eds.): Boundary and Space: An Introduction to the Work of D. W. Winnicott 330

Gumaer, Jim: Counseling and Therapy for Children 570

Jaffe, Eliezer D.: Israelis in Institutions: Studies in Child Placement, Practice and Policy 218

Kaye, Kenneth: The Mental and Social Life of Babies: How Parents Create Persons 220

Lewis, Michael (Ed.): Beyond the Dyad. Genesis of Behaviour: Vol. 4331

Moss, Howard A., Hess, Robert and Swift, Carolyn (Eds.): Early Intervention Programs for Infants 678

Prugh, Dane G.: The Psychological Aspects of Pediatrics 113

\section{COMMUNITY PSYCHIATRY}

Bateson, Nicholas: Data Construction in Social Surveys 340
Martin, F. M.: Between the Acts: Community Mental Health Services 1959-1983 564

Pedersen, Paul B., Sartorius, Norman and Marsella, Anthony J. (Eds.): Mental Health Services: The CrossCultural Context 221

Reed, John and Lomas, Gillian (Eds.): Psychiatric Services in the Community: Developments and Innovations 217

Sutcliffe, Anthony (Ed.): Metropolis 1890-1940 453

Wilson, Holly Skodol: Deinstitutionalised Residential Care for the Mentally Disordered: The Soteria House Approach 217

\section{DEPRESSION}

Levitt, Eugene E., Lubin, Bernard and Brooks, James $M$. Depression: Concepts, Controversies, and Some New Facts 569

Wetzel, Janice Wood: Clinical Handbook of Depression 684

\section{DIAGNOSIS, MANAGEMENT AND TREATMENT}

Brooks, Neil (Ed.): Closed Head Injury: Psychological, Social and Family Consequences 225

Dubin, W. R., Hanke, N. and Nickens, H. W. (Eds.): Psychiatric Emergencies. Clinics in Emergency Medicine 336

Hanke, Nancy: Handbook of Emergency Psychiatry 570 Joffe, Justin M., Albee, George W. and Kelly, Linda D. (Eds.): Readings in Primary Prevention of Psychopathology: Basic Concepts 219

Jones, Kathleen and Fowles, A. J.: Ideas on Institutions Analysing the Literature on Long-Term Care and Custody 220

Levy, Norman B. (Ed.): Psychonephrology 2-Psychological Problems in Kidney Failure and their Treatment 568

Manschreck, Theo C. and Murray, George B. (Eds.): Psychiatric Medicine Update 337

Scull, Andrew: Decarceration-Community Treatment and the Deviant-A Radical View. 2nd edition 334

Steptoe, Andrew and Mathews, Andrew (Eds.): Health Care and Human Behaviour 339

Talbott, John A (Ed.): The Chronic Mental Patient: Five Years Later 682

Trower, Peter (Ed.): Radical Approaches to Social Skills Training 334

Tupin, Joe E., Halbreich, Uriel and Pena, Jesus J. (Eds.): Transient Psychosis: Diagnosis, Management and Evaluation 226

Van Ments, Morry: The Effective Use of Role-Play: A Handbook for Teachers and Trainers 340

\section{FEMALE ISSUES}

Golub, Sharon (Ed.): Lifting the Curse of Menstruation: A Feminist Appraisal of the Influence of Menstruation on Women's Lives 457

Greene, John Gerald: The Social and Psychological Origins of the Climacteric Syndrome 457

Krueger, David W.: Success and the Fear of Success in Women 680 
Penfold, P. Susan and Walker, Gillian A.: Women and the Psychiatric Paradox 681

Walker, Lenore E.: The Battered Woman Syndrome 569

\section{FORENSIC}

Craft, Michael and Ann (Eds.): Mentally Abnormal Offenders 222

Masters, Brian: Killing for Company: The Case of Dennis Nilsen 684

\section{GENERAL}

Crown, Sidney (Ed.): Contemporary Psychiatry 329

Dunn, C. Gibson(Ed.): Textbook of Contemporary Psychiatry 683

Freedman, Daniel X., Talbott, John A., Lourie, Reginald S., Meltzer, Herbert Y., Nemiah, John C. and Weiner, Herbert (Eds.): 1984 Year Book of Psychiatry and Applied Mental Health 566

Gaind, Raghu N., Fawzy, Fawzy I., Hudson, Barbara L. and Pasnau, Robert O. (Eds.): Current Themes in Psychiatry: Vol. 3. 112

Lidz, Charles W., Meisel, Alan, Zerubavel, Eviatar, Carter, Mary, Sestak, Regina M. and Roth, Loren H.: Informed Consent: A Study of Decisionmaking in Psychiatry 109

Morgan, H. G. and Morgan, M. H.: Aids to Psychiatry. 2nd edition 339

Russell, G. F. M. and Hersov, L. A. (Eds.): Handbook of Psychiatry. Vol. 4. The Neuroses and Personality Disorders 562

Sims, A. C. P. and Hume, W. 1. (Eds.): Lecture Notes on Behavioural Sciences 456

Weller, Malcolm(Ed.): The Scientific Basis of Psychiatry 226

\section{HISTORY}

Donnelly, Michael: Managing the Mind: A Study of Medical Psychology in Early Nineteenth-Century Britain 331

Johnson, F. Neil (Ed.): The History of Lithium Therapy 677

\section{HYPNOSIS}

Hilgard, Ernest R. and Josephine, R.: Hypnosis in the Relief of Pain. Revised edition 335

Waxman, David: Psychological Influences and Illness: Hypnosis and Medicine 569

Wester, William C. and Smith, Alexander H., Jr. (Eds.): Clinical Hypnosis: A Multi-disciplinary Approach 568

\section{LEGAL}

Whitehead, Tony: Mental Illness and the Law. Revised edition after the 1983 Act 453

\section{MENTAL HANDICAP}

Clark, David G. (Ed.): Help, Hospitals and the Handicapped 224
Heaton-Ward, W. Alan and Wiley, Yvonne: Mental Handicap (formerly Mental Subnormality) Fifth Edition 339

\section{MISCELLANEOUS}

Galler, Janina K. (Ed.): Human Nutrition-A Comprehensive Treatise. Vol. 5. Nutrition and Behaviour 108

Popper, Kare R. and Eccles, John C.: The Self and its Brain. An Argument for Interactionism 107

Sargant, William: The Unquiet Mind 567

Smith, Joseph H. and Kerrigan, William (Eds.): Interpreting Lacan 336

\section{MOOD DISORDERS}

Post, Robert M. and Ballenger, James C. (Eds.): Neurobiology of Mood Disorders 106

Whybrow, P. C., Akiskal, H. S. and McKinney, W. T., Jr.: Mood Disorders-Toward a New Psychobiology 110

\section{RELIGION}

Foskett, John: Meaning in Madness: The Pastor and the Mentally III 679

Meissner, W. W.: Psychoanalysis and Religious Experience 679

Shapiro, Deane H. and Walsh, Roger N. (Eds.): Meditation: Classic and Contemporary Perceptions 454

\section{NEUROLOGY}

Harrison, M. J. G. (Ed.): Contemporary Neurology 331

\section{PSYCHOGERIATRICS}

Bromley, P. B. (Ed.): Gerontology: Social and Behavioural Perspectives 338

Cooper, Edwin L. (Ed.): Stress, Immunity and Ageing 338

Salzman, Carl (Ed.): Clinical Geriatric PsychoPharmacology.

Wertheimer, Jean and Marois, Maurice (Eds.): Senile Dementia-Outlook for the Future 330

\section{PSYCHOLOGY}

Nash, Eleanor, Stoch, Belle and Harper, Glynis: Human Behaviour 564

Orme, J. E.: Abnormal and Clinical Psychology: An Introductory Text 337

Samuels, Andrew: Jung and the Post-Jungians 678

\section{PSYCHOPHARMACOLOGY}

Burrows, Graham D., Norman, Trevor, R. and Davies, Brian (Eds.): Anti-Anxiety Agents-Drugs in Psychiatry, Vol. 2327

Carlton, Peter L.: A Primer of Behavioural Pharmacology 329

Donlon, Patrick, Schaffer, Charles, Ericksen, Stephen, Pepitone-Arreola-Rockwell, Frances and Schaffer, Linda: a Manual of Psychotropic Drugs: A Mental Health Resource 111

Johnson, F. Neil (Ed.): The Psychopharmacology of Lithium 677

Trimble, Michael R. and Zarifian, E. (Eds.): Psychopharmacology of the Limbic System 221 


\section{PSYCHOSEXUAL}

Feldman, Harold and Parrot, Andrea (Eds.): Human Sexuality-Contemporary Controversies 333

Krane, Robert J., Siroky, Mike B. and Goldstein, Irwin (Eds.): Male Sexual Dysfunction. 223

\section{RESEARCH}

Morozov, P. V. (Ed.): Research on the Viral Hypothesis of Mental Disorders 105

Shepherd, Michael (Ed.): The Spectrum of Psychiatric Research 565

Tricklebank, M. D. and Curzon, G. (Eds.): StressInduced Analgesia 676

\section{SOCIAL WORK}

Goldberg, E. Matilda, Gibbons, Jane and Sinclair, Ian: Problems, Tasks and Outcomes: The Evaluation of Task-Centred Casework in Three Settings 567

\section{THERAPIES}

Beier, Ernst G. and Young, David M.: The Silent Language of Psychotherapy 110

Boyer, L. Bryce: The Regressed Patient 227

Caligor, Leopold, Bromberg, Philip M. and Meltzer, James D. (Eds.): Clinical Perspective on the Supervision of Psychoanalysis and Psychotherapy 111

Dalley, Tessa (Eds.): Art as Therapy. An Introduction to the Use of Art as a Therapeutic Technique 566
Madanes, Cloe: Behind the One-Way Mirror: Advances in the Practice of Strategic Therapy 332

Parsons, Richard D. and Wicks, Robert J. (Eds.): PassiveAggressiveness. Theory and Practice 112

Sank, Lawrence I. and Shaffer, Carolyn S.: A Therapist's Manual for Cognitive Behaviour Therapy in Groups 112

Schultz, Stephen J.: Family Systems Therapy: An Integration 458

Sullivan, John L. and Sullivan, Paula DeRemer: Biomedical Psychiatric Therapeutics 676

Verger, Michael, Jurkovic, Gregory and Associates: Practising Family Therapy in Diverse Settings 682

Werman, David S.: The Practice of Supportive Psychotherapy 563

Wolberg, Lewis R. and Aronson, Marvin (Eds.): Group and Family Therapy 1983224

\section{TRANSCULTURAL}

Brown, Stephen (Ed.): Psychiatry in Developing Countries 223

Rack, Philip H.: Race, Culture, and Mental Disorder 219

\section{CORRECTION}

Journal, April 1985, 146, 341-347 'Understanding the Italian Experience'. The reference to Sarteschi, Cassano, Mauri \& Petracca on page 347 should read (1985). Current status of psychiatric care in Italy. In Psychiatry, Human Rights and the Law (eds. M. Roth and R. Bluglass). Cambridge University Press. 
We would like to thank the following who have acted as specialist assessors of original papers

\begin{tabular}{|c|c|c|c|}
\hline M. T. Abou-Saleh & T. G. Crookes & Kathleen Jones & S. Platt \\
\hline P. Abraham & T. J. Crow & J. H. Kahn & J. Pollitt \\
\hline D. Adshead & K. Davison & R. E. Kendell & F. Post \\
\hline G. B. Ansell & K. A. Day & P. F. Kennedy & P. Rabbitt \\
\hline T. H. D. Arie & D. Eccleston & I. Kolvin & P. H. Rack \\
\hline G. Ashcroft & Guy Edwards & N. Kreitman & D. Raistrick \\
\hline M. Aveline & M. D. Enoch & R. Kumar & J. L. Reed \\
\hline J. H. J. Bancroft & B. J. Essex & R. P. Liberman & Naomi Richman \\
\hline T. R. E. Barnes & C. Fairburn & M. Lipsedge & K. J. B. Rix \\
\hline B. Barnett & M. Faulk & R. Littlewood & R. Rodnight \\
\hline B. Barraclough & G. W. Fenton & G. G. Lloyd & O. Russell \\
\hline M. Beary & I. N. Ferrier & C. McCance & D. R. Rutter \\
\hline Linda Beeley & C. Freeman & H. A. McClelland & P. Salkovskis \\
\hline G. Bennett & C. D. Frith & R. J. McClelland & C. P. Seager \\
\hline I. Berg & T. Fryers & R. G. McCreadie & D. M. Shaw \\
\hline G. E. Berrios & Ann Gath & P. McGuffin & G. Sheppard \\
\hline P.J. V. Beumont & M. G. Gelder & A. V. P. Mackay & T. Silverstone \\
\hline Joan Bicknell & J. P. Gent & Sheila A. Mann & A. C. P. Sims \\
\hline J. L. T. Birley & A. H. Ghodse & R. Marchbanks & D. Smith \\
\hline Dora Black & D. Goldberg & I. Marks & G. Stein \\
\hline G. Blessed & R. E. Goodman & A. Mathews & J. Steinert \\
\hline P. Bowden & D. G. Grahame-Smith & R. Mayou & R. S. Stern \\
\hline S. Brandon & H. Gurling & R. Meadow & A. Strachan \\
\hline C. Brewer & D. Hand & R. H. S. Mindham & J. Strang \\
\hline G. Brindley & E. H. Hare & S. A. Montgomery & G. Szmukler \\
\hline I. F. Brockington & M. A. Harper & E. Moran & N. Tarrier \\
\hline A. Burke & Tirril Harris & H. G. Morgan & Pamela J. Taylor \\
\hline A. Campbell & K. Hawton & S. Morley & Katherine Tress \\
\hline M. W. P. Carney & L. Hemsi & D. Nutt & M. Trimble \\
\hline G. M. Carstairs & D. R. Hemsley & J. Orley & S. P. Tyrer \\
\hline D. Chiswick & A. S. Henderson & I. Oswald & Margaret Vaughan \\
\hline P. H. Connell & R. P. Hullin & D. Owens & J. Wattis \\
\hline J. Cookson & W. I. Hume & R. Palmer & D. Weeks \\
\hline P. Cooper & J. G. Ingham & C. M. B. Pare & M. Weller \\
\hline R. Cooter & A. Jablensky & C. M. Parkes & L. J. Whalley \\
\hline P.J. Cowen & A. L. Johnson & E. S. Paykel & D. Wheatley \\
\hline Valerie A. Cowie & D. A. W. Johnson & D. J. Pearson & Lorna Wing \\
\hline J. L. Cox & Eve C. Johnstone & J. R. Pedder & S. Wood \\
\hline J. L. Crammer & D. J.Jolley & J. Pickstone & R. T. Woods \\
\hline F. Creed & H. G.Jones & J. Pippard & T. Wykes \\
\hline & & B. Pitt & Celia Yates \\
\hline
\end{tabular}

